\title{
Association Between the Method of Delivery and Respiratory Outcomes in Extremely Preterm and Extremely Low Birth Weight Infants: a Retrospective Cohort Study in Newborns From 2000-2003
}

\author{
Eleonora G.M. Vosbeek ( $\sim$ noortjevosbeek@gmail.com ) \\ Maastricht University Faculty of Health, Medicine and Life Sciences: Maastricht Universitair Medisch Centrum+ \\ https://orcid.org/0000-0003-3103-1590
}

\author{
Rosanne J.H.C.G. Beijers \\ Maastricht UMC+: Maastricht Universitair Medisch Centrum+ \\ Willem J.M. Gerver \\ Maastricht UMC+: Maastricht Universitair Medisch Centrum+ \\ Jan G. Nijhuis \\ Maastricht UMC+: Maastricht Universitair Medisch Centrum+

\section{Boris W.W. Kramer} \\ Maastricht UMC+: Maastricht Universitair Medisch Centrum+
}

\section{Research}

Keywords: method of delivery, vaginal birth, cesarean section, respiratory outcomes, respiratory distress syndrome, bronchopulmonary dysplasia, ventilatory treatment, extremely preterm, extremely low birth weight

Posted Date: March 15th, 2021

DOI: https://doi.org/10.21203/rs.3.rs-290662/v1

License: (c) (i) This work is licensed under a Creative Commons Attribution 4.0 International License. Read Full License 


\section{Abstract}

Background: Extremely preterm (gestational age (GA) $<28$ weeks) and extremely low birth weight (ELBW) infants $(<1000 \mathrm{~g})$ are at risk to develop respiratory morbidities like respiratory distress syndrome (RDS), bronchopulmonary dysplasia (BPD) and pneumothorax. The delivery method also influences respiratory outcomes, with cesarean sections (CS) being associated with a higher incidence of RDS, pneumothorax and ventilatory treatment. To develop new preventive or early respiratory treatment strategies for high-risk neonates, knowledge about risk factors for respiratory outcomes in this group is necessary. This study aims to investigate the association between the delivery method and respiratory outcomes in extremely preterm and ELBW infants.

Methods: We performed a retrospective patient record cohort study of all extremely preterm and/or ELBW neonates born between 2000-2003 in a tertiary center in Maastricht, the Netherlands. Differences in RDS, BPD, pneumothorax, invasive mechanical ventilation (MV), continuous positive airway pressure (CPAP), nasal oxygen, duration of invasive MV, CPAP and total respiratory support, nitric oxide, surfactant and postnatal steroids with pulmonary indication between vaginal delivery (VD) and CS were assessed.

Results: A total of 172 infants were included. The CS group $(n=119)$ had a higher mean GA, percentage males and prevalence of multiple gestations compared to the VD group $(n=53)(p<0.05)$. Furthermore, birth weight, birth weight standard deviation score (SDS) and weight at discharge were lower in the CS group $(\mathrm{p}<0.05)$. Fetal distress and moderate 1minute Apgar scores (4-6) were more common in the CS group, as was premature rupture of membranes. Low 1-minute Apgar scores (0-3), persistent ductus arteriosus and intraventricular hemorrhage occurred more frequently in the VD group, as did pre-eclampsia or 'hemolysis elevated liver enzymes low platelet count'-syndrome. After correcting for GA and birth weight SDS, a significant association between CS and receiving surfactant was found. Other primary respiratory outcomes and treatments did not show any associations.

Conclusions: After correcting for GA and birth weight SDS, the method of delivery is not associated with adverse respiratory outcomes in extremely preterm and ELBW infants. Due to changes in standard operating procedures, additional prospective research should focus on infants born more recently.

Trial registration: Not applicable.

\section{Background}

Yearly, approximately 1 million babies in developed countries are born preterm (before 37 weeks of gestational age (GA)), which corresponds to $8.6 \%$ of all births in these countries. Trends show that rates of prematurity are increasing, which makes it a substantial burden $[1,2]$. Prematurity and low birth weight (LBW) are known to be important risk factors for neonatal morbidity and mortality $[3,4]$. Low birth weight can be defined as very low (VLBW) and extremely low (ELBW) when birth weight is lower than 1500 or 1000 grams, respectively [5]. Complications of preterm birth lead to an estimated $35 \%$ of deaths among newborns, making them the leading cause of neonatal deaths [6]. Respiratory morbidities in particular are the number one cause of neonatal intensive care admissions [7]. Neonatal respiratory morbidity is inversely related with GA and birth weight, since lung development is not fully completed at the time of delivery, making infants born extremely preterm and those with an ELBW belong to the most vulnerable group $[4,7,8]$. Preterm birth is a complex entity in which the adaptation from a fluid filled uterus to air breathing is essential. A mature surfactant system and a perinatal catecholamine surge are necessary for effective lung fluid clearance at birth [7-11].

The disturbances caused by an underdeveloped respiratory system may cause respiratory distress syndrome (RDS), a disease of progressive alveolar collapse which occurs in $60-80 \%$ of extremely premature (<28 weeks GA) and ELBW infants $[3,7]$. These infants often have a need of ventilation with positive pressure to increase surfactant production and secretion [9]. Optimal treatment includes oxygen administration and mechanical ventilation (MV), which is nevertheless accompanied 
by several risks like atelectotrauma, volutrauma and the forming of free radicals [7]. These affect vascular and alveolar development and thus injure the immature lung. The lung damage in preterm and VLBW infants caused by requiring MV and oxygen therapy for prolonged periods, can lead to the development of bronchopulmonary dysplasia (BPD) [3, 7, 11]. BPD is characterized by alveolar hypoplasia, saccular wall fibrosis and variable smooth muscle hyperplasia causing a reduction in the surface area available for gas exchange. The exact pathogenesis remains unknown, but immaturity of the pulmonary vasculature, inflammation and high airway pressure are thought to play a key role in the progression of lung damage $[7,12$, 13]. BPD occurs mostly in extremely preterm $(<28$ weeks GA) and/or ELBW infants $[7,13,14]$ and with more of these infants surviving, the incidence of BPD among this group is increasing [15]. Another complication of MV is overinflation, which may lead to alveolar rupture and subsequently pneumothorax, a potential life-threatening condition with a high mortality rate [7].

Next to prematurity and ventilatory treatment, the method of delivery may also contribute to adverse respiratory outcomes in neonates. Cesarean section (CS) is known to reduce perinatal passive lung fluid clearance from the airspaces, impeding gas exchange $[8,11]$. Furthermore, these infants are known to reach lower catecholamine levels than infants born vaginally, leading to a lower surfactant secretion [11]. The method of delivery may be associated with mechanical ventilation, a known risk factor for respiratory morbidities [16-18]. An association between CS and the risk of RDS and pneumothorax was found $[19,20]$, but large studies on the method of delivery associated with BPD are not available. Known risk factors for respiratory morbidities, such as CS, are thought to act differently in different GA groups [21]. Earlier studies confirm the association between CS and respiratory morbidities in moderate and late preterms (GA 30-37 weeks) and suggest that lower GA further increases this risk [22-25], as does low birth weight independently [21, 26, 27]. A study in Norway investigated CS in very preterm newborns ( $\leq 29$ weeks $\mathrm{GA}$ ) with outcomes of pneumothorax and the need for continuous positive airway pressure (CPAP) and MV [28]. BPD has only been taken into account as a separate outcome in a group of breech-presenting neonates of 23-24 weeks GA [29] and in twins between 26-31 weeks GA [30].

There is only limited knowledge about the influence of the method of delivery on respiratory outcomes in extremely preterm and ELBW infants, a high-risk group, with a lack of information on the diagnosis BPD. The aim of the current study was to investigate whether there is an association between the method of delivery and respiratory morbidity and ventilatory treatment in extremely preterm and ELBW infants. Knowledge about whether there is an association between the method of delivery and respiratory treatment, MV in particular, and developing RDS, pneumothorax and/or BPD in extremely preterm and ELBW infants can contribute to an earlier identification of newborns at risk in whom (new) preventive and/or early supportive treatment strategies could be most effective.

\section{Methods}

\section{Study design and subjects}

In order to investigate the association between the method of delivery and respiratory morbidity in extremely preterm and ELBW infants, a retrospective patient record cohort study was performed within the Maastricht University Medical Centre+ (MUMC+) in the Netherlands. Eligible patients were identified from the Dutch national neonatal registration (LNR) database. Using systematic sampling, all extremely preterm neonates, defined as being born at a GA of 28 weeks or below, and ELBW neonates, defined as a birth weight of 1000 grams or below, independent of GA, born between the 1st of January 2000 and 31st of December 2003 in the MUMC + or elsewhere but admitted to the MUMC + in the neonatal period were eligible for inclusion. This specific time period was chosen because of a future long-term follow-up study within this group. Exclusion criteria were unavailable neonatal medical records, transportation to another center on the first day and chromosomal and major congenital anomalies. The study protocol received a declaration of not being subject to the 'Medical Research Involving Human Subjects Act'(WMO), meaning that no ethical approval was required by the ethical review committee of the MUMC+ (research number: METC 2019 - 1311).

\section{Data extraction}


The data collection was done by one investigator (EV). All clinical discharge letters and outpatient letters from birth until the age of five years as well as available letters from other hospitals where the patient was admitted in the neonatal period, were reviewed. Additionally, when available, data from the registration form and post-mortem reports were collected to obtain extra information. Research data were encoded and saved, to ensure patient confidentiality.

From the medical records the following data was extracted: the method of delivery, general characteristics, including sex, GA, head circumference, weight at birth and at discharge, multiple gestation, administration of antenatal steroids, causes of prematurity, early postnatal outcomes, respiratory treatment including pharmacological treatment, surgery, death and duration of stay in the hospital and in the NICU. For the method of delivery, a distinction was made between cesarean and vaginal birth, where instrument-assisted vaginal birth was included in the total of vaginal births. Fetal distress was defined as cardiotocography abormalities, an umbilical arterial pH below 7.20 or amniotic fluid containing meconium and premature rupture of membranes (PROM) as a rupture of membranes of more than 24 hours before labor. Antenatal steroid use was defined as at least one documented administration. Birth weight SDS was calculated using a calculation program by Gerver and de Bruin [31]. Every intervention done within 15 minutes after birth to stimulate breathing or circulation was labeled as resuscitation at birth. Moreover, invasive mechanical ventilation included high frequency (oscillatory) ventilation $(H F(0) \mathrm{V})$, intermittent positive-pressure ventilation (IPPV) and nasal and synchronized intermittent mandatory ventilation (nIMV and SIMV, respectively). The total amount of days during which an infant received either invasive MV, CPAP or oxygen, was labeled as total respiratory support time. For this study, abruptio placentae and pre-eclampsia or hemolysis elevated liver enzymes low platelet count (HELLP) syndrome were subsumed from the diagnoses stated by the clinicians as documented in the patient records. Postnatal morbidities, including RDS, BPD, pneumothorax, persistent ductus arteriosus (PDA), necrotizing enterocolitis (NEC), gastrointestinal perforation, sepsis, intraventricular hemorrhage (IVH) and periventricular leukomalacia (PVL), were obtained likewise. In case of a bilateral IVH, the side with the highest grade was documented.

\section{Sample size}

A broad literature search was done, but no previous studies showing results of the effect of the method of delivery on duration of respiratory treatment were found. We therefore calculated the sample size using a difference $(\delta)$ in incidence of MV of $4.4 \%$ and a presumed standard deviation (SD) of $8 \%$, based on the study by Benterud et al. [28]. Using the formula of Sachs [32], a sample size of 52 patients per group was needed.

\section{Statistical analysis}

Data were analyzed using Statistical Package for the Social Sciences (SPSS version 25 for Windows, SPSS Inc. Chicago, IL). Normal distribution of variables was checked with a Shapiro-Wilk test and by visual assessment of histograms. A chi-square test or fisher exact test, depending on the expected count in the cells, was used to evaluate categorical variables. For continuous variables a two-sided independent sample t-test was used for normally distributed data and a Mann-Whitney $U$ test for data with skewed distributions. Differences were considered significant when $p<0.05$. Patient characteristics exhibiting statistically significant differences were considered to be potential confounders. In order to investigate associations between the delivery method and respiratory outcomes as well as the duration of respiratory treatment, logistic regression analyses were performed for categorical variables and linear regression analyses for continuous variables. These models were first performed unadjusted (model 0 ). In a stepwise approach, clinical risk factors were statistically evaluated. All subsequent models (model 1-6) were adjusted for MV since this is a known risk factor for BPD and pneumothorax [3, 7, 11] and for GA and birth weight SDS, based on the literature which has shown that these factors directly influence neonatal outcomes $[4,7,8]$. Model 2-6 were additionally adjusted for the preventive therapy of antenatal steroids, which has been proven to reduce the incidence of RDS and the need for MV $[20,33]$. In model 3 we adjusted for postpartum adaptation problems, by adding 1-minute Apgar score [34]. In the next step, we adjusted for stressful perinatal conditions, which is defined as fetal distress (model 4) [35]. Model 5 was adjusted for both fetal distress and postpartum adaptation problems. Finally, model 6 was adjusted for fetal distress plus 5-minute Apgar scores, to adjust for infants who had stressful perinatal conditions and those who were still in a poor condition after delivery room interventions, since this is known to be associated with poorer neonatal outcomes $[34,36]$. Assumptions to perform linear regression models were checked.

Page $4 / 16$ 


\section{Results}

\section{Patient characteristics}

In total, 189 patients have been identified as extremely preterm and/or ELBW. Of these, 17 were excluded due to unavailable records, transportation to other centers or chromosomal or major congenital anomalies. Therefore, 172 neonates were included in the current analysis [Figure 1], of which $69.2 \%$ were born by CS.

Of the total of 172 enrolled patients, 110 infants were singletons, 56 infants were part of twin pregnancies and 6 infants of triplets [Table 1]. Triplets were more prevalent in the CS group, while twins were more prevalent in the VD group. The CS group included significantly less males and had a significantly higher GA compared to the VD group [Figure 2A and 2D], while birth weight [Figure 2B and 2E] and birth weight SDS [Figure 2C and 2F] were significantly lower. The incidences of fetal distress, pre-eclampsia and HELLP were higher in the CS group, whilst the incidences of PROM and other causes of preterm birth were higher in the VD group. Directly after birth, infants born by CS exhibited a significantly lower umbilical arterial $\mathrm{pH}$ and were more likely to receive moderate (4-6) 1-minute Apgar scores. Children born vaginally were given normal (7-10) and low (0-3) 1-minute Apgar scores more frequently. PDA and IVH occurred less frequently in the CS group and the infants in this group had a lower weight at discharge compared to the VD infants. After adjusting for GA and birth weight SDS, no associations between the method of delivery and PDA and IVH were seen anymore [Additional file 1]. This remained after additional adjustment with antenatal steroids, 1-minute Apgar score, fetal distress and 5-minute Apgar score combined in 6 different models.

\section{Respiratory outcomes}

No differences in respiratory morbidity and respiratory treatment, including pharmacological treatment, were found between CS and VD infants [Model 0, Table 2 and additional file 2]. After correcting for the confounders GA and birth weight SDS, CS was both significantly and independently associated with receiving surfactant therapy in the neonatal period [Model 1]. This association seemed to remain after additional adjustment with antenatal steroids [Model 2] and 1-minute Apgar score [Model 3]. After correcting for GA, birth weight SDS and additionally for antenatal steroids and 1-minute Apgar score, no other associations were found between the method of delivery and other respiratory outcomes [Model 1-3]. After accounting for fetal distress and antenatal steroids [Model 4] and additionally for 1-minute Apgar score [Model 5] and 5minute Apgar score [Model 6], no associations between the method of delivery and respiratory outcomes were found. Also, no independent association was found between the method of delivery and duration of respiratory treatment [Table 3]. Adjusting all 6 models for surfactant revealed no significant associations [Additional file 3].

\section{Discussion}

In order to develop new, preventive and/or early supportive respiratory treatment strategies for extremely preterm newborns, registration and correlation of the clinical data on risk factors and clinical respiratory outcomes is necessary. We therefore studied the association between the method of delivery and respiratory outcomes in extremely preterm and ELBW infants, who were born between 2000-2003 in the MUMC+. A non-equal distribution of GA and birth weight SDS was found between VD infants and CS infants, with different risk profiles for preterm birth indication and respiratory outcomes. This finding was unexpected. However, the standardized operating procedures (SOPs) which were applied in the Netherlands during those years were different from the SOPs which are currently applied. Preterm CS with an indication of IUGR were almost never conducted below a GA of 28 weeks because of a 'no, unless'-policy [37], resulting in most of the births $<28$ weeks being VD.

Since preterm birth is directly associated with poorer neonatal outcomes, we were not surprised to find different incidences for PDA and IVH [38]. Furthermore, LBW correlates with a lower functional residual capacity (FRC) and causes a more compliant chest wall, leading to more difficulties in drawing the first breath [7]. This makes growth restriction an important confounder for respiratory outcomes. Therefore, as expected, these differences disappeared after correcting for the most 
important confounders: GA, birth weight SDS, antenatal steroids, fetal distress, 1-minute Apgar score and 5-minute Apgar score. An independent association was found between the method of delivery and surfactant, after adjusting for GA and birth weight SDS. This confirms the knowledge that CS may lead to a lower endogenous surfactant secretion due to lower catecholamine levels, causing these infants to be in need of exogenous surfactant therapy [11]. The higher catecholamine levels during fetal distress on the other hand, explain why this association disappears after correcting for fetal distress [39].

Surprisingly, no other independent associations were found between the delivery method and respiratory morbidity, invasive MV and CPAP. This is in contrast to the study by Werner et al. who did find an association between CS and RDS [40]. However, the latter study included a different patient group, namely preterms (25-34 weeks GA) who were small for GA (birth weight $<10$ th percentile of standard birth weight for their GA). In another study in preterms ( $\leq 30-36$ weeks GA), a higher incidence of pneumothorax was reported in the CS group and preterms in this group were more in need of CPAP and MV [28]. The discrepancies in results between these studies and ours could be due to the different study populations. Still, our findings were consistent with Sangkomkamhang et al. [41], who reported no difference in the incidence of RDS, although they also included a different study population (infants born at GA $\leq 36$ weeks). Since a difference in surfactant treatment was found between our two groups, we speculated that preventive treatment might have been applied more effectively in the CS group. This was tested by additionally adjusting for surfactant in all the models [Additional file 3], which should eliminate differences in RDS and pneumothorax diagnosis but not in BPD incidence [42]. However, an influence of surfactant on respiratory morbidity and respiratory support was not found. Another possible explanation was the lack of maternal medical information, which might contain confounders. No information about the onset of labor was taken into account, because this information was unavailable. The CS infants of the mothers who were already in labor are thought to have better respiratory outcomes due to a higher catecholamine release and a higher uterine tone because of present contractions. The surfactant system is activated during labor and an increase of cortisol and thyroid hormones as a reaction to the birth process promote the neonatal transition from fetal to extrauterine lung function $[9,43]$. A large proportion of emergency CS in our cohort could have influenced the magnitude of our results. We therefore speculated that the birth process of the CS group in this study was more stimulating regarding the neonatal respiratory transition, than the birth of infants born by CS at a higher GA. This could then explain why there were less respiratory complications in our group than expected. To further investigate this, future studies should focus on respiratory outcomes after CS, adjusted for different GA groups.

One of the strengths of this study was that it was conducted in the only regional tertiary center in the Dutch province of Limburg, where care has been based on SOPs for attending policy. Multiple outcomes were documented in a database, combining several documents from the medical files of the patients, which improves the quality of the data. In order to reduce individual variation in care, the Netherlands have embraced SOPs very early [44]. Therefore, we rated the possibility of high variation in the clinical decision-making among the attending physicians neglectable. This was in particular highlighted in the SOP of surfactant treatment, in which precise cut offs for oxygen therapy mandating surfactant treatment are given. Furthermore, performing statistical corrections for potential confounders made our results more truthful. A limitation, however, was that data were collected retrospectively, leading to an inability to control exposure or outcome assessment and the need to rely on the accurate recordkeeping of others. Also, the 3-year interval of data collection and sample size were limitations. The diagnosis BPD has difficulties in itself, because the current definitions require a postmenstrual age of 36 weeks before classification can be done accurately [45]. The limitation of having an assessment at one time point is that infants who have died prior to this age, but who would have developed BPD later on, could not be included in the analyses. This may have led to seemingly better outcomes in BPD infants, because of missing recording of the outcomes of infants in the worst condition and clinical course. We have corrected for the problem of missing the recording of infants who were transferred or discharged before 36 weeks' postmenstrual age, and who had thus not been diagnosed with BPD yet, by collecting data from medical records until the age of five. We, however, refrained from a combined outcome of death or BPD, which has been used to deal with this shortcoming [46].

\section{Conclusions}


Extremely preterm and ELBW infants belong to the group of neonates which is most at risk of adverse respiratory outcomes. We included two groups of preterm infants, who were delivered by different methods on account of the SOPs at that time and who proved to have different risk profiles for respiratory outcomes. The clinical implication of the group differences must be further studied in particular with long term outcomes at adult age. Our results suggest that after correcting for GA and birth weight SDS, the method of delivery is not associated with adverse respiratory outcomes in this high-risk group. Since SOPs have changed since 2003 , additional prospective research should focus on infants born more recently.

\section{Abbreviations}

BPD = bronchopulmonary dysplasia

CPAP = continuous positive airway pressure

$\delta=$ difference

ELBW $=$ extremely low birth weight

$\mathrm{FRC}=$ functional residual capacity

$\mathrm{GA}=$ gestational age

HELLP = hemolysis elevated liver enzymes low platelet count

HFOV = high frequency oscillatory ventilation

$\mathrm{HFV}=$ high frequency ventilation

IPPV = intermittent positive-pressure ventilation

$\mathrm{IQR}=$ interquartile range

IUGR = intrauterine growth restriction

$\mathrm{IVH}=$ intraventricular hemorrhage

LBW = low birth weight

LNR = Landelijke Neonaten Registratie (= Dutch national neonatal registration)

MUMC+ = Maastricht University Medical Centre +

$\mathrm{MV}=$ mechanical ventilation

NEC $=$ necrotizing enterocolitis

$\mathrm{nIMV}=$ nasal intermittent mandatory ventilation

PDA = persistent ductus arteriosus

PROM = premature rupture of membranes

$\mathrm{PVL}=$ periventricular leukomalacia

RDS = respiratory distress syndrome 
$\mathrm{SD}=$ standard deviation

SDS = standard deviation score

sIMV = synchronized intermittent mandatory ventilation

SOP = standardized operating procedure

TTN = transient tachypnea of the newborn

VD = vaginal delivery

VLBW = very low birth weight

\section{Declarations}

- Ethics approval and consent to participate: The study received a non-WMO declaration by the ethical review committee of the MUMC+ (research number: 2019-1311).

- Consent for publication: Not applicable.

- Availability of data and materials: The datasets used and analyzed during the current study are available from the corresponding author on reasonable request.

- Competing interests: The authors declare that they have no competing interests.

- Funding: Not applicable.

- Authors' contributions: Concept of study: BK, EV, RB, WG; Collected data from medical records: EV; Interpreted data and performed statistical analyses: EV, RB, BK, JN; Wrote manuscript: EV; Edited and approved manuscript: EV, RB, BK, WG, JN.

- Acknowledgements: The authors want to thank M.A.H.B.M. van der Hoeven, MD PhD, for assisting in obtaining the medical records.

\section{References}

1. Blencowe H, Cousens S, Oestergaard MZ, Chou D, Moller AB, Narwal R, et al. National, regional, and worldwide estimates of preterm birth rates in the year 2010 with time trends since 1990 for selected countries: a systematic analysis and implications. Lancet. 2012;379(9832):2162-72.

2. Harrison MS, Goldenberg RL. Global burden of prematurity. Semin Fetal Neonatal Med. 2016;21(2):74-9.

3. Stoll BJ, Adams-Chapman I. 97. The High-Risk Infant. In: Kliegman RM, Behrman RE, Jenson HB, Stanton BM, editors. Nelson textbook of pediatrics e-book: Elsevier Health Sciences; 2007.

4. Saigal S, Doyle LW. An overview of mortality and sequelae of preterm birth from infancy to adulthood. The Lancet. 2008;371(9608):261-9.

5. World Health O. International statistical classification of diseases and related health problems. 10th revision, Fifth edition, 2016 ed. Geneva: World Health Organization; 20152015.

6. Levels and Trends in Child Mortality. Report 2019. Estimates developed by the UN Inter-agency Group for Child Mortality Estimation. New York: United Nations Children's Fund; 2019.

7. Dudell GG, Stoll BJ. 101. Respiratory Tract Disorders. In: Kliegman RM, Behrman RE, Jenson HB, Stanton BM, editors. Nelson textbook of pediatrics e-book: Elsevier Health Sciences; 2007. 
8. Smith LJ, McKay KO, van Asperen PP, Selvadurai H, Fitzgerald DA. Normal development of the lung and premature birth. Paediatr Respir Rev. 2010;11(3):135-42.

9. Morton SU, Brodsky D. Fetal Physiology and the Transition to Extrauterine Life. Clin Perinatol. 2016;43(3):395-407.

10. Bhutani VK, editor Extrauterine adaptations in the newborn. Seminars in Neonatology; 1997: Elsevier.

11. Hillman NH, Kallapur SG, Jobe AH. Physiology of transition from intrauterine to extrauterine life. Clinics in perinatology. 2012;39(4):769-83.

12. Jobe AH. The new bronchopulmonary dysplasia. Current opinion in pediatrics. 2011;23(2):167.

13. Keller RL, Ballard RA. Bronchopulmonary dysplasia. Avery's diseases of the newborn: Elsevier; 2018. p. 678-94. e6.

14. Carlson AM, Hariharan S. Bronchopulmonary Dysplasia. Imaging in Pediatrics: Elsevier; 2018. p. 56-7.

15. Stoll BJ, Hansen NI, Bell EF, Walsh MC, Carlo WA, Shankaran S, et al. Trends in Care Practices, Morbidity, and Mortality of Extremely Preterm Neonates, 1993-2012. Jama. 2015;314(10):1039-51.

16. Jain L, Eaton DC. Physiology of fetal lung fluid clearance and the effect of labor. Semin Perinatol. 2006;30(1):34-43.

17. Indraccolo U, Pace M, Corona G, Bonito M, Indraccolo SR, Di lorio R. Cesarean section in the absence of labor and risk of respiratory complications in newborns: a case-control study. J Matern Fetal Neonatal Med. 2019;32(7):1160-6.

18. Ramachandrappa A, Jain L. Elective cesarean section: its impact on neonatal respiratory outcome. Clin Perinatol. 2008;35(2):373-93, vii.

19. Ji L, Huang NN, Chen D. Etiology and prevention of neonatal pneumothorax. Zhongguo Dang Dai Er Ke Za Zhi. 2013;15(8):623-6.

20. Zhang H, Liu J, Liu T, Wang Y, Dai W. Antenatal maternal medication administration in preventing respiratory distress syndrome of premature infants: A network meta-analysis. Clin Respir J. 2018;12(10):2480-90.

21. Condò V, Cipriani S, Colnaghi M, Bellù R, Zanini R, Bulfoni C, et al. Neonatal respiratory distress syndrome: are risk factors the same in preterm and term infants? J Matern Fetal Neonatal Med. 2017;30(11):1267-72.

22. Correia C, Rocha G, Flor-de-Lima F, Guimaraes H. Respiratory morbidity in late preterm infants. Minerva Pediatr. 2018;70(4):345-54.

23. Altman $M$, Vanpee $M$, Cnattingius S, Norman M. Risk factors for acute respiratory morbidity in moderately preterm infants. Paediatr Perinat Epidemiol. 2013;27(2):172-81.

24. Berthelot-Ricou A, Lacroze V, Courbiere B, Guidicelli B, Gamerre M, Simeoni U. Respiratory distress syndrome after elective caesarean section in near term infants: a 5-year cohort study. J Matern Fetal Neonatal Med. 2013;26(2):176-82.

25. Heinzmann A, Brugger M, Engels C, Prömpeler H, Superti-Furga A, Strauch K, et al. Risk factors of neonatal respiratory distress following vaginal delivery and caesarean section in the German population. Acta Paediatr. 2009;98(1):25-30.

26. Zhu J-J, Bao Y-Y, Zhang G-L, Ma L-X, Wu M-Y. No relationship between mode of delivery and neonatal mortality and neurodevelopment in very low birth weight infants aged two years. World Journal of Pediatrics. 2014;10(3):227-31.

27. Stanley FJ, Alberman ED. Infants of very low birthweight. II: Perinatal factors in and conditions associated with respiratory distress syndrome. Dev Med Child Neurol. 1978;20(3):313-22.

28. Benterud T, Sandvik L, Lindemann R. Cesarean section is associated with more frequent pneumothorax and respiratory problems in the neonate. Acta Obstet Gynecol Scand. 2009;88(3):359-61.

29. Tucker Edmonds B, McKenzie F, Macheras M, Srinivas SK, Lorch SA. Morbidity and mortality associated with mode of delivery for breech periviable deliveries. Am J Obstet Gynecol. 2015;213(1):70.e1-.e12.

30. Sentilhes L, Oppenheimer A, Bouhours AC, Normand E, Haddad B, Descamps P, et al. Neonatal outcome of very preterm twins: policy of planned vaginal or cesarean delivery. Am J Obstet Gynecol. 2015;213(1):73.e1-.e7.

31. Gerver W, de Bruin R. Pediatric Morphometrics: a Reference Manual. Maastricht. University Press Maastricht; 2001.

32. Sachs L. Applied statistics: a handbook of techniques: Springer Science \& Business Media; 2012. 
33. Roberts D, Brown J, Medley N, Dalziel SR. Antenatal corticosteroids for accelerating fetal lung maturation for women at risk of preterm birth. Cochrane Database Syst Rev. 2017;3(3):Cd004454.

34. Goldsmith J. Overview and initial management of delivery room resuscitation. Fanaroff and Martin's neonatal-perinatal medicine: Elsevier Saunders Philadelphia, PA; 2020. p. 516-29.

35. Hackney DN. Estimation of Fetal Well-Being. Fanaroff and Martin's neonatal-perinatal medicine: Elsevier Saunders Philadelphia, PA; 2020. p. 210-22.

36. Thavarajah $\mathrm{H}$, Flatley $\mathrm{C}$, Kumar S. The relationship between the five minute Apgar score, mode of birth and neonatal outcomes. J Matern Fetal Neonatal Med. 2018;31(10):1335-41.

37. Specialisten KvdFvM. Perinataal beleid bij extreme vroeggeboorte. Actieve neonatologische opvang bij extreme vroeggeboorte2010.

38. Fanaroff AA, Stoll BJ, Wright LL, Carlo WA, Ehrenkranz RA, Stark AR, et al. Trends in neonatal morbidity and mortality for very low birthweight infants. Am J Obstet Gynecol. 2007;196(2):147.e1-8.

39. Noori S, Friedlich PS, Seri I. 156. Pathophysiology of Shock in the Fetus and Neonate. In: Polin RA, Abman SH, Rowitch DH, Benitz WE, Fox WW, editors. Fetal and Neonatal Physiology. Fifth edition ed. Philadelphia: Elsevier; 2017.

40. Werner EF, Savitz DA, Janevic TM, Ehsanipoor RM, Thung SF, Funai EF, et al. Mode of delivery and neonatal outcomes in preterm, small-for-gestational-age newborns. Obstet Gynecol. 2012;120(3):560-4.

41. Sangkomkamhang U, Pattanittum P, Laopaiboon M, Lumbiganon P. Mode of delivery and outcomes in preterm births. $J$ Med Assoc Thai. 2011;94(4):415-20.

42. Soll R. Prophylactic synthetic surfactant for preventing morbidity and mortality in preterm infants. Cochrane Database of Systematic Reviews. 1998(2).

43. Milner AD, Vyas H. Lung expansion at birth. J Pediatr. 1982;101(6):879-86.

44. Healthcare in the Netherlands. The Hague: Ministry of Health, Welfare and Sport; 2018.

45. Bancalari E, Jain D. Bronchopulmonary Dysplasia: Can We Agree on a Definition? Am J Perinatol. 2018;35(6):537-40.

46. Onland W, Cools F, Kroon A, Rademaker K, Merkus MP, Dijk PH, et al. Effect of Hydrocortisone Therapy Initiated 7 to 14 Days After Birth on Mortality or Bronchopulmonary Dysplasia Among Very Preterm Infants Receiving Mechanical Ventilation: A Randomized Clinical Trial. Jama. 2019;321(4):354-63.

\section{Tables}


Table 1

Patient demographics of vaginal birth infants $(n=53)$ and cesarean birth infants $(n=119)$

\begin{tabular}{|c|c|c|c|}
\hline & \multirow{2}{*}{$\begin{array}{l}\text { Vaginal birth infants } \\
(n=53)\end{array}$} & \multirow{2}{*}{$\begin{array}{l}\text { Cesarean birth infants } \\
(n=119)\end{array}$} & \multirow[t]{2}{*}{$p$-value } \\
\hline & & & \\
\hline \multicolumn{4}{|l|}{ General characteristics } \\
\hline Male sex, n (\%) & $33(62.3 \%)$ & $53(44.5 \%)$ & 0.032 \\
\hline Head circumference on day $3^{\mathrm{b}}(\mathrm{cm})$ & $24.8 \pm 1.5$ & $24.7 \pm 1.7$ & 0.739 \\
\hline Multiple gestation & & & 0.002 \\
\hline Twins, n (\%) & 27 (50.9\%) & $29(24.4 \%)$ & \\
\hline Triplets, n (\%) & $0(0.0 \%)$ & $6(5.0 \%)$ & \\
\hline Antenatal steroids ${ }^{c}, n(\%)$ & $34(75.6 \%)$ & $73(84.9 \%)$ & 0.109 \\
\hline \multicolumn{4}{|l|}{ Causes of prematurity } \\
\hline Fetal distress ${ }^{d}, n(\%)$ & $14(26.9 \%)$ & $91(76.5 \%)$ & $<0.001$ \\
\hline PROM, n (\%) & $20(37.7 \%)$ & $14(11.8 \%)$ & $<0.001$ \\
\hline Abruptio placentae, $n$ (\%) & $2(3.8 \%)$ & $5(4.2 \%)$ & $>0.999$ \\
\hline Pre-eclampsia/HELLP ${ }^{\mathrm{e}}, \mathrm{n}(\%)$ & $0(0.0 \%)$ & $47(39.5 \%)$ & $<0.001$ \\
\hline Other, n (\%) & $41(77.4 \%)$ & $39(32.8 \%)$ & $<0.001$ \\
\hline \multicolumn{4}{|l|}{ Early postnatal outcomes } \\
\hline Umbilical arterial blood $\mathrm{pH}^{\mathrm{f}}$ & $7.25(7.11-7.34)$ & $7.17(7.10-7.25)$ & 0.013 \\
\hline 1-minute Apgar score $\mathrm{g}$ & & & 0.037 \\
\hline 7-10, n (\%) & $23(44.2 \%)$ & $47(39.8 \%)$ & \\
\hline $4-6, n(\%)$ & $16(30.8 \%)$ & $57(48.3 \%)$ & \\
\hline $0-3, n(\%)$ & $13(25.0)$ & $14(11.9 \%)$ & \\
\hline 5-minute Apgar score ${ }^{\mathrm{h}}$ & & & 0.159 \\
\hline 7-10, n (\%) & $39(78.0 \%)$ & $104(88.1 \%)$ & \\
\hline $4-6, n(\%)$ & $9(18.0 \%)$ & $11(9.3 \%)$ & \\
\hline $0-3, n(\%)$ & $2(4.0 \%)$ & $3(2.5 \%)$ & \\
\hline Resuscitation at birth i, n (\%) & $39(75.0 \%)$ & $72(60.5 \%)$ & 0.068 \\
\hline \multicolumn{4}{|l|}{ Postnatal morbidity } \\
\hline $\mathrm{PDA}^{\mathrm{j}}, \mathrm{n}(\%)$ & $21(39.6 \%)$ & $20(16.9 \%)$ & 0.001 \\
\hline NEC total, n (\%) & $4(7.5 \%)$ & $22(18.5 \%)$ & 0.209 \\
\hline radiologically proven, n (\%) & $3(5.7 \%)$ & $14(11.8 \%)$ & \\
\hline clinical suspicion, n (\%) & $1(1.9 \%)$ & $8(6.7 \%)$ & \\
\hline
\end{tabular}




\begin{tabular}{|c|c|c|c|}
\hline & Vaginal birth infants & Cesarean birth infants & $p$-value \\
\hline & $(n=53)$ & $(n=119)$ & \\
\hline Gastrointestinal perforation, $\mathrm{n}(\%)$ & $2(3.8 \%)$ & $10(8.4 \%)$ & 0.347 \\
\hline Sepsis, n (\%) & $32(60.4 \%)$ & $77(64.7 \%)$ & 0.586 \\
\hline IVH total, n (\%) & $27(50.9 \%)$ & $33(27.7 \%)$ & 0.003 \\
\hline Grade $1-2, \mathrm{n}(\%)$ & $17(32.1 \%)$ & $23(19.3 \%)$ & 0.068 \\
\hline Grade 3-4, n (\%) & $10(18.9 \%)$ & $10(8.4 \%)$ & 0.048 \\
\hline PVL, n (\%) & $3(5.7 \%)$ & $5(4.2 \%)$ & 0.703 \\
\hline Treatment & & & \\
\hline Postnatal steroids, indication hypotensio & & & \\
\hline Surgery, n (\%) & $10(18.9 \%)$ & $25(21.0 \%)$ & 0.747 \\
\hline & $5(9.4 \%)$ & $18(15.1 \%)$ & 0.311 \\
\hline Mortality during hospital stay, n (\%) & $13(26.4 \%)$ & $19(16.0 \%)$ & 0.108 \\
\hline Duration of hospital stay (days) & $42.0(10.0-67.0)$ & $35.0(16.0-67.0)$ & 0.962 \\
\hline Duration of stay in NICU k (days) & $18.0(6.0-44.5)$ & $24.0(11.0-38.5)$ & 0.338 \\
\hline Weight at discharge ' $(\mathrm{kg})$ & $1.755 \pm 0.491$ & $1.531 \pm 0.623$ & 0.029 \\
\hline Head circumference at discharge ${ }^{m}(\mathrm{~cm})$ & $30.5 \pm 2.9$ & $29.9 \pm 4.0$ & 0.468 \\
\hline $\begin{array}{l}\text { Normally distributed variables are presen } \\
\text { categorical variables as number of subjec } \\
=\text { Hemolysis Elevated Liver enzymes Low } \\
\text { persistent ductus arteriosus. PROM = prer } \\
\text { standard deviation score. Alphabetic char } \\
\text { following: a. } n=165 \text { (VD and CS, resp. } 46 \\
45 \text { and } 86), d . n=171 \text { (VD and CS, resp. } 5 \\
\text { resp. } 33 \text { and } 69), g . n=170 \text { (VD and CS, } \\
\text { CS, resp. } 52 \text { and } 119), j \text { j. } n=171 \text { (VD and } \\
\text { and CS, resp. } 39 \text { and } 97) \text {, and } m \text {. } n=76 \text { (V }\end{array}$ & $\begin{array}{l}\text { D, non-normally distrib } \\
\text { in bold indicates a sigr } \\
\text { IQR = interquartile rang } \\
\text { of membranes. PVL }=p \\
\text { cript indicates a sampl } \\
=79 \text { (VD and CS, resp. } \\
=171 \text { (VD and CS, res } \\
\text { 8), h. } n=168 \text { (VD and C } \\
\text { d } 118), k . n=103 \text { (VD a } \\
21 \text { and } 55) \text {. }\end{array}$ & $\begin{array}{l}\text { d variables as median (I } \\
\text { ant difference. Abbrevia } \\
\text { JEC = necrotizing enteroc } \\
\text { entricular leukomalacia. } \\
\text { ze deviant from } n=172, \\
\text { and } 59), c . n=131(\mathrm{VD} \text { a } \\
2 \text { and } 119), \mathrm{f} . \mathrm{n}=102(\mathrm{~V} \\
\text { esp. } 50 \text { and } 118), \mathrm{i} . \mathrm{n}=1 \\
\mathrm{SS} \text {, resp. } 34 \text { and } 69), \mathrm{I} . \mathrm{n}\end{array}$ & $\begin{array}{l}\text { and } \\
\text { S: HELLP } \\
\text { S. PDA = } \\
\text { S= } \\
\text { the } \\
\text { S, resp. } \\
\text { Id CS, } \\
\text { VD and } \\
6 \text { (VD }\end{array}$ \\
\hline
\end{tabular}


Table 2

Logistic regression model analyses investigating the independent associations between the delivery method and respiratory outcomes.

\begin{tabular}{|c|c|c|c|c|c|c|c|}
\hline & Model 0 & Model 1 & Model 2 & Model 3 & Model 4 & Model 5 & Model 6 \\
\hline & Unadjusted & $\begin{array}{l}\text { Standard } \\
\text { adjustment } \\
\$\end{array}$ & $\begin{array}{l}\text { Standard } \\
\text { adjustment } \\
\$\end{array}$ & $\begin{array}{l}\text { Standard } \\
\text { adjustment } \\
\$\end{array}$ & $\begin{array}{l}\text { Standard } \\
\text { adjustment } \\
\$\end{array}$ & $\begin{array}{l}\text { Standard } \\
\text { adjustment } \\
\$\end{array}$ & $\begin{array}{l}\text { Standard } \\
\text { adjustment } \\
\$\end{array}$ \\
\hline & $\mathrm{OR}(\mathrm{Cl})$ & OR (Cl) & $\begin{array}{l}\text { + antenatal } \\
\text { steroids }\end{array}$ & $\begin{array}{l}\text { + antenatal } \\
\text { steroids }\end{array}$ & $\begin{array}{l}\text { + antenatal } \\
\text { steroids }\end{array}$ & $\begin{array}{l}\text { + antenatal } \\
\text { steroids }\end{array}$ & $\begin{array}{l}\text { + antenatal } \\
\text { steroids }\end{array}$ \\
\hline & & & $\mathrm{OR}(\mathrm{Cl})$ & $\begin{array}{l}\text { +1-minute } \\
\text { Apgar } \\
\text { score }\end{array}$ & $\begin{array}{l}\text { + fetal } \\
\text { distress }\end{array}$ & $\begin{array}{l}\text { +1-minute } \\
\text { Apgar } \\
\text { score }\end{array}$ & $\begin{array}{l}\text { + 5-minute } \\
\text { Apgar } \\
\text { score }\end{array}$ \\
\hline & & & & OR (Cl) & OR (Cl) & $\begin{array}{l}\text { + fetal } \\
\text { distress }\end{array}$ & $\begin{array}{l}\text { + fetal } \\
\text { distress }\end{array}$ \\
\hline & & & & & & OR (Cl) & OR (Cl) \\
\hline $\begin{array}{l}\text { Respiratory } \\
\text { morbidity }\end{array}$ & & & & & & & \\
\hline RDS & $\begin{array}{l}0.743 \\
(0.341- \\
1.622)\end{array}$ & $\begin{array}{l}2.618 \\
(0.679- \\
10.086)^{a}\end{array}$ & $\begin{array}{l}2.336 \\
(0.482- \\
11.317)^{c}\end{array}$ & $\begin{array}{l}3.140 \\
(0.562- \\
17.541)^{e}\end{array}$ & $\begin{array}{l}2.198 \\
(0.429- \\
11.262)^{c}\end{array}$ & $\begin{array}{l}3.250 \\
(0.547- \\
19.318)^{\mathrm{e}}\end{array}$ & $\begin{array}{l}2.196 \\
(0.388- \\
12.429)^{g}\end{array}$ \\
\hline BPD & $\begin{array}{l}0.603 \\
(0.300- \\
1.212)\end{array}$ & $\begin{array}{l}1.379 \\
(0.416- \\
4.572)^{a}\end{array}$ & $\begin{array}{l}1.343 \\
(0.321- \\
5.611)^{\mathrm{c}}\end{array}$ & $\begin{array}{l}1.286 \\
(0.299- \\
5.527)^{e}\end{array}$ & $\begin{array}{l}1.271 \\
(0.290- \\
5.571)^{c}\end{array}$ & $\begin{array}{l}1.325 \\
(0.291- \\
6.043)^{\mathrm{e}}\end{array}$ & $\begin{array}{l}1.191 \\
(0.268- \\
5.293)^{g}\end{array}$ \\
\hline Pneumothorax & $\begin{array}{l}0.490 \\
(0.156- \\
1.534)\end{array}$ & $\begin{array}{l}1.349 \\
(0.258- \\
7.053)^{a}\end{array}$ & $\begin{array}{l}1.469 \\
(0.282- \\
7.650)^{c}\end{array}$ & $\begin{array}{l}1.424 \\
(0.270- \\
7.514)^{e}\end{array}$ & $\begin{array}{l}1.229 \\
(0.199- \\
7.590)^{c}\end{array}$ & $\begin{array}{l}1.197 \\
(0.192- \\
7.462)^{\mathrm{e}}\end{array}$ & $\begin{array}{l}1.154 \\
(0.181- \\
7.361)^{g}\end{array}$ \\
\hline $\begin{array}{l}\text { Respiratory } \\
\text { treatment }\end{array}$ & & & & & & & \\
\hline Invasive MV & $\begin{array}{l}0.558 \\
(0.253- \\
1.234)\end{array}$ & $\begin{array}{l}2.097 \\
(0.693- \\
6.343)^{b}\end{array}$ & $\begin{array}{l}2.815 \\
(0.740- \\
10.715)^{d}\end{array}$ & $\begin{array}{l}3.174 \\
(0.746- \\
13.505)^{f}\end{array}$ & $\begin{array}{l}1.268 \\
(0.295- \\
5.447)^{d}\end{array}$ & $\begin{array}{l}1.690 \\
(0.376- \\
7.604)^{f}\end{array}$ & $\begin{array}{l}1.510 \\
(0.334- \\
6.818)^{h}\end{array}$ \\
\hline CPAP & $\begin{array}{l}1.498 \\
(0.700- \\
3.209)\end{array}$ & $\begin{array}{l}1.118 \\
(0.372- \\
3.354)^{b}\end{array}$ & $\begin{array}{l}0.999 \\
(0.296- \\
3.377)^{d}\end{array}$ & $\begin{array}{l}1.047 \\
(0.306- \\
3.580)^{f}\end{array}$ & $\begin{array}{l}0.826 \\
(0.213- \\
3.206)^{d}\end{array}$ & $\begin{array}{l}0.850 \\
(0.216- \\
3.342)^{f}\end{array}$ & $\begin{array}{l}0.899 \\
(0.226- \\
3.570)^{h}\end{array}$ \\
\hline Nasal oxygen & $\begin{array}{l}1.791 \\
(0.831- \\
3.859)\end{array}$ & $\begin{array}{l}1.814 \\
(0.710- \\
4.634)^{b}\end{array}$ & $\begin{array}{l}1.769 \\
(0.624- \\
5.014) d\end{array}$ & $\begin{array}{l}1.695 \\
(0.548- \\
4.919)^{f}\end{array}$ & $\begin{array}{l}1.365 \\
(0.436- \\
4.270)^{d}\end{array}$ & $\begin{array}{l}1.444 \\
(0.450- \\
4.639)^{f}\end{array}$ & $\begin{array}{l}1.457 \\
(0.450- \\
4.724)^{h}\end{array}$ \\
\hline $\begin{array}{l}\text { Pharmacologica } \\
\text { treatment }\end{array}$ & & & & & & & \\
\hline Nitric oxide & $\begin{array}{l}1.044 \\
(0.378- \\
2.886)\end{array}$ & $\begin{array}{l}3.149 \\
(0.780- \\
12.716)^{b}\end{array}$ & $\begin{array}{l}4.096 \\
(0.883- \\
18.998) d \#\end{array}$ & $\begin{array}{l}4.523 \\
(0.905- \\
22.618)^{f \#}\end{array}$ & $\begin{array}{l}3.744 \\
(0.709- \\
19.780)^{d}\end{array}$ & $\begin{array}{l}5.581 \\
(0.904- \\
34.376)^{f \#}\end{array}$ & $\begin{array}{l}3.648 \\
(0.688- \\
19.350)^{h}\end{array}$ \\
\hline Surfactant & $\begin{array}{l}0.840 \\
(0.438- \\
1.609)\end{array}$ & $\begin{array}{l}3.070 \\
(1.205- \\
7.819)^{b} \text { * }\end{array}$ & $\begin{array}{l}2.935 \\
(0.958- \\
8.991)^{d \#}\end{array}$ & $\begin{array}{l}3.139 \\
(0.952- \\
10.355)^{f \#}\end{array}$ & $\begin{array}{l}1.991 \\
(0.604- \\
6.566)^{d}\end{array}$ & $\begin{array}{l}2.385 \\
(0.679- \\
8.374)^{f}\end{array}$ & $\begin{array}{l}2.110 \\
(0.606- \\
0.7346)^{h}\end{array}$ \\
\hline $\begin{array}{l}\text { Postnatal } \\
\text { steroids }\end{array}$ & $\begin{array}{l}0.719 \\
(0.247- \\
2.092)\end{array}$ & $\begin{array}{l}1.036 \\
(0.257- \\
4.187)^{b}\end{array}$ & $\begin{array}{l}1.548 \\
(0.332- \\
7.232)^{d}\end{array}$ & $\begin{array}{l}1.513 \\
(0.318- \\
7.206)^{f}\end{array}$ & $\begin{array}{l}1.693 \\
(0.306- \\
9.371)^{d}\end{array}$ & $\begin{array}{l}2.064 \\
(0.346- \\
12.309)^{f}\end{array}$ & $\begin{array}{l}1.861 \\
(0.328- \\
10.551)^{h}\end{array}$ \\
\hline
\end{tabular}


Odds ratios $(\mathrm{OR})$ and corresponding confidence intervals $(\mathrm{Cl})$ are given for $\mathrm{CS}$. Abbreviations: $\mathrm{BPD}=$ bronchopulmonary dysplasia. $\mathrm{Cl}=$ confidence interval. $\mathrm{CPAP}=$ continuous positive airway pressure. $\mathrm{MV}=$ mechanical ventilation. $\mathrm{RDS}=$ respiratory distress syndrome. Alphabetic character in superscript indicates a sample size deviant from $n=172$, with the following: a. $n=149, b . n=165$, c. $n=114, d$. $n=124$, e. $n=113, f . n=123, g . n=112, h . n=122$. $\$=$ Adjusted models were standard corrected for GA and birth weight SDS and respiratory morbidities were additionally standard corrected for MV time. ${ }^{*}=$ p-value $<0.05, \#=$-value $<0.1$.

Table 3

Linear regression model analyses investigating independent associations of the delivery method and duration of respiratory treatment.

\begin{tabular}{|c|c|c|c|c|c|c|c|}
\hline & Model 0 & Model 1 & Model 2 & Model 3 & Model 4 & Model 5 & Model 6 \\
\hline & Unadjusted & $\begin{array}{l}\text { Standard } \\
\text { adjustment } \\
\$\end{array}$ & $\begin{array}{l}\text { Standard } \\
\text { adjustment } \\
\$\end{array}$ & $\begin{array}{l}\text { Standard } \\
\text { adjustment } \\
\$\end{array}$ & $\begin{array}{l}\text { Standard } \\
\text { adjustment } \\
\$\end{array}$ & $\begin{array}{l}\text { Standard } \\
\text { adjustment } \\
\$\end{array}$ & $\begin{array}{l}\text { Standard } \\
\text { adjustment } \\
\$\end{array}$ \\
\hline & B (SE) & B (SE) & $\begin{array}{l}\text { + antenatal } \\
\text { steroids }\end{array}$ & $\begin{array}{l}\text { + antenatal } \\
\text { steroids }\end{array}$ & $\begin{array}{l}\text { + antenatal } \\
\text { steroids }\end{array}$ & $\begin{array}{l}\text { + antenatal } \\
\text { steroids }\end{array}$ & $\begin{array}{l}\text { + antenatal } \\
\text { steroids }\end{array}$ \\
\hline & & & B (SE) & $\begin{array}{l}\text { +1-minute } \\
\text { Apgar score }\end{array}$ & $\begin{array}{l}+ \text { fetal } \\
\text { distress }\end{array}$ & $\begin{array}{l}\text { +1-minute } \\
\text { Apgar score }\end{array}$ & $\begin{array}{l}\text { + 5-minute } \\
\text { Apgar score }\end{array}$ \\
\hline & & & & B (SE) & B (SE) & $\begin{array}{l}\text { + fetal } \\
\text { distress }\end{array}$ & $\begin{array}{l}\text { + fetal } \\
\text { distress }\end{array}$ \\
\hline & & & & & & B (SE) & B (SE) \\
\hline Invasive MV & $\begin{array}{l}-0.991 \\
(2.034)^{a}\end{array}$ & $\begin{array}{l}1.747 \\
(2.478)^{c}\end{array}$ & $\begin{array}{l}2.405 \\
(3.011) \mathrm{e}\end{array}$ & $\begin{array}{l}2.313 \\
(3.065)^{h}\end{array}$ & $\begin{array}{l}1.448 \\
(3.259) \mathrm{e}\end{array}$ & $\begin{array}{l}1.722 \\
(3.315)^{h}\end{array}$ & $\begin{array}{l}1.312 \\
(3.328) k\end{array}$ \\
\hline CPAP & $\begin{array}{l}-1.406 \\
(2.432)^{b}\end{array}$ & $\begin{array}{l}-1.272 \\
(2.999) \mathrm{d}\end{array}$ & $\begin{array}{l}-0.681 \\
(3.484)^{f}\end{array}$ & $\begin{array}{l}-0.928 \\
(3.577) i\end{array}$ & $\begin{array}{l}-2.089 \\
(3.753)^{f}\end{array}$ & $\begin{array}{l}-2.110 \\
(3.840) i\end{array}$ & $\begin{array}{l}-2.337 \\
(3.879)^{g}\end{array}$ \\
\hline $\begin{array}{l}\text { Total } \\
\text { respiratory } \\
\text { support }\end{array}$ & $\begin{array}{l}-3.735 \\
(5.044)^{b}\end{array}$ & $\begin{array}{l}-3.913 \\
(6.004) d\end{array}$ & $\begin{array}{l}-0.793 \\
(6.069) \mathrm{g}\end{array}$ & $\begin{array}{l}-0.667 \\
(6.136)^{j}\end{array}$ & $\begin{array}{l}-3.100 \\
(6.494)^{g}\end{array}$ & $\begin{array}{l}-1.689 \\
(6.623)^{j}\end{array}$ & $\begin{array}{l}-4.080 \\
(6.642) ।\end{array}$ \\
\hline $\begin{array}{l}\text { Variables are } \\
<0.05, \text { nor }<0 \text {. } \\
\text { character in } s \\
149, \mathrm{~d} \text {. } \mathrm{n}=13 \\
\text { models were }\end{array}$ & $\begin{array}{l}\text { sented as ur } \\
\text { Abbreviations } \\
\text { erscript indic } \\
n=114, \mathrm{f} \text {. } \\
\text { ndard correc }\end{array}$ & Candardized $b$ & a (B) with the & $\begin{array}{l}\text { corresponding } \\
\text { rway pressure. }\end{array}$ & $\begin{array}{l}\text { andard error } \\
\mathrm{AV}=\text { mechani } \\
\text { e following: a } \\
3, \mathrm{k} . \mathrm{n}=112 \text {, }\end{array}$ & $\begin{array}{l}\text { E). There wer } \\
\text { al ventilation. } \\
n=156, b . n= \\
\text { d } I . n=102 \text {. }\end{array}$ & $\begin{array}{l}\text { 1o } p \text {-values } \\
\text { phabetic } \\
42, c \cdot n= \\
=\text { Adjusted }\end{array}$ \\
\hline
\end{tabular}

Figures 


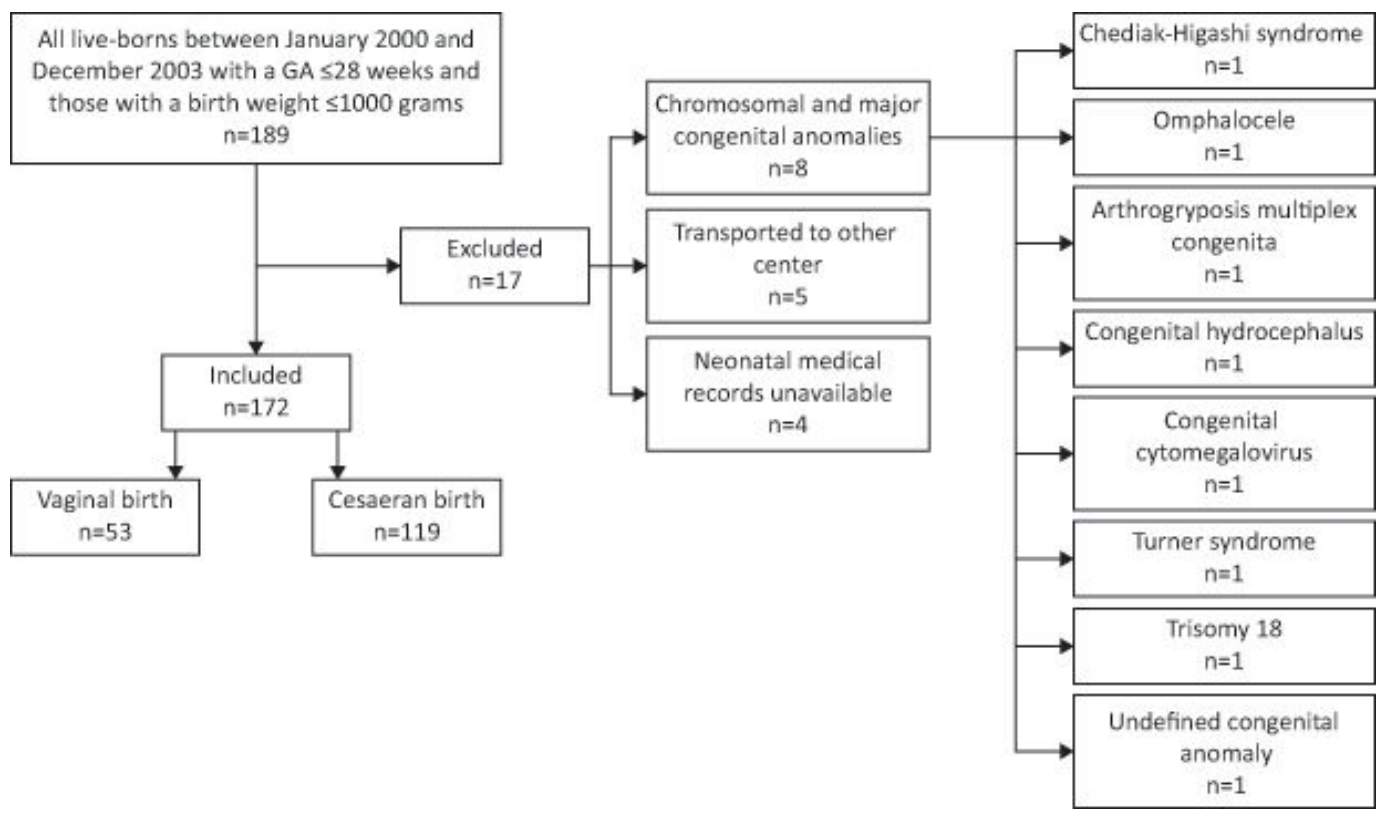

Figure 1

Study population flowchart
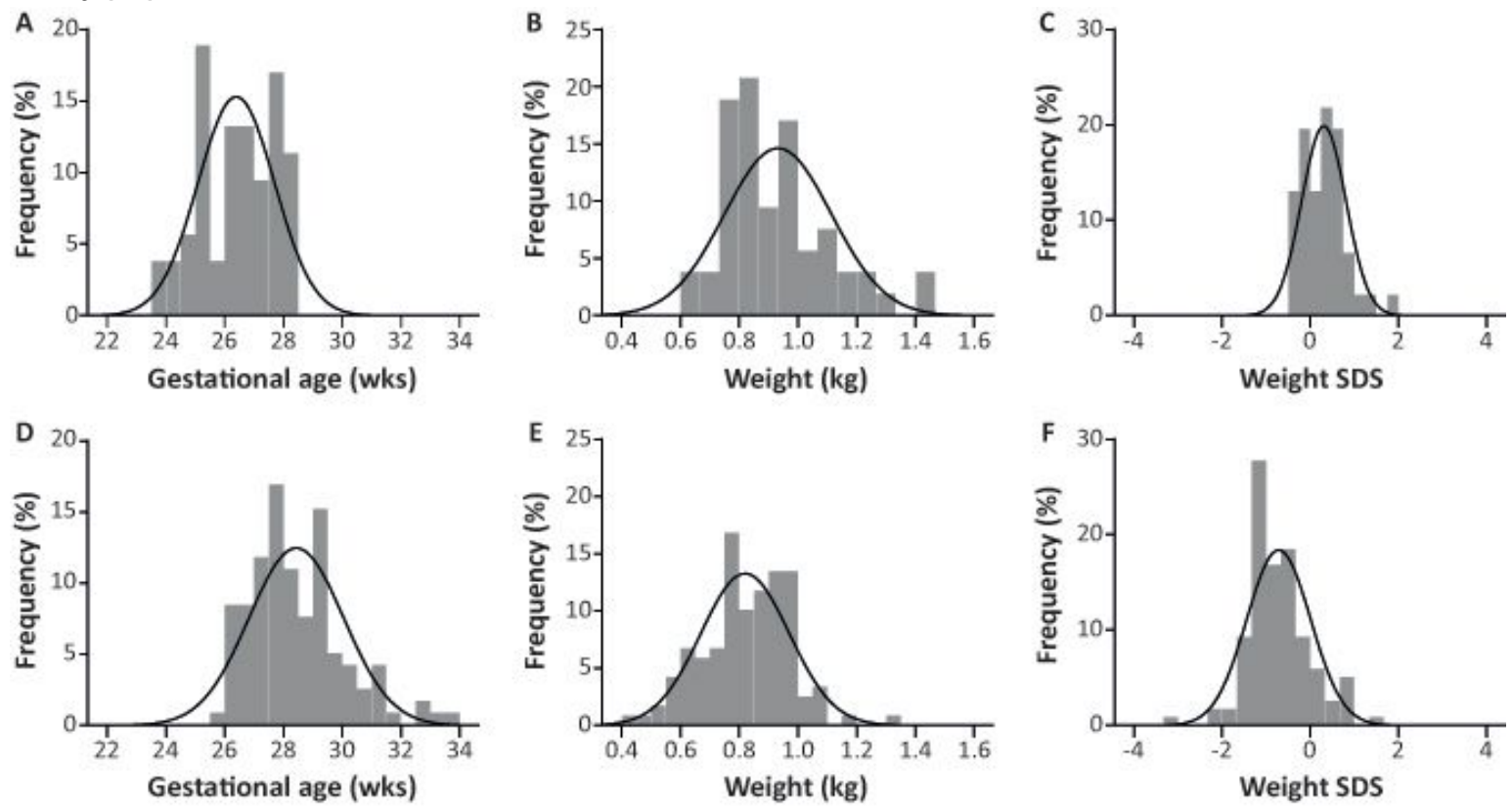

Figure 2

Normality curves for patient characteristics. $p<0.001$ for all variables. A) Gestational age in vaginal birth infants $(n=53$, mean $\pm S D=26.4 \pm 1.3)$; B) Birth weight in vaginal birth infants $(n=53$, mean $\pm S D=0.932 \pm 0.182)$; $)$ Birth weight SDS in vaginal birth infants $(n=46$, mean $\pm S D=0.31 \pm 0.50)$; $D)$ Gestational age in cesarean birth infants $(n=119$, mean $\pm S D=$ $28.4 \pm 1.6)$; $E$ ) Birth weight in cesarean birth infants $(n=119$, mean $\pm S D=0.820 \pm 0.150)$; $F$ ) Birth weight SDS in cesarean birth infants $(n=119$, mean $\pm S D=-0.72 \pm 0.72)$.

\section{Supplementary Files}

This is a list of supplementary files associated with this preprint. Click to download. 
- Additionalfile1.xlsx

- Additionalfile2.xIsx

- Additionalfile3.xIsx 